\title{
$\mathrm{GC}$ 及び GC/MS によるワイン中のメチル イソチオシアネートの分析法
}

(平成 4 年 7 月 16 日受理)

\begin{tabular}{|c|c|c|}
\hline 内 山貞夫 ${ }^{* 1, * 2}$ & 武 田 寿*2 & 小林昭彦*2 \\
\hline 伊 藤 澄夫夫² & 桜井裕之朕 & 多田善彦*2 \\
\hline 青 木 岳*2 & 細 貝 猛*2 & 山中崇彰*2 \\
\hline $\begin{array}{l}\text { 前川吉 明*3 } \\
\text { 斎藤行 生*1 }\end{array}$ & 吉川礼 次 ${ }^{* 4}$ & 伊藤一夫林 \\
\hline
\end{tabular}

\section{Determination of Methyl Isothiocyanate in Wine by GC and GC/MS}

\author{
Sadao Uchiy ama ${ }^{* 1, * 2}$, Hisashi TakedA ${ }^{* 2}$, Akihiko Kobay ashi ${ }^{* 2}$, Sumio Ito*2, \\ Hiroyuki Sakurai*2, Yoshihiko TAdA ${ }^{* 2}$, Gaku Aokı*2, Takashi Hosogar*2, \\ Takaaki YamanakA*2, Yoshiaki MaEkawA ${ }^{* 3}$, Reiji Yoshikawa*4, \\ Kazuo ITo*4 and Yukio SAITo*1 \\ (*1 National Institute of Hygienic Sciences: 1-18-1, Kamiyoga, Setagaya-ku, Tokyo 158, Japan; \\ ${ }^{* 2}$ Center for Inspection of imported Foods and Infectious Diseases,Yokohama Quarantine \\ Station: 107-8, Nagahama, Kanazawa-ku, Yokohama, Kanagawa 236, Japan; ${ }^{* 3}$ Japan \\ Food Research Laboratories: 6-11-10, Nagayama, Tama, Tokyo 206, Japan; \\ ${ }^{* 4}$ The Japan Canned Food Inspection Association: 2-15, \\ Kitanakamichi, Naka-ku, Yokohama 231, Japan)
}

A simple and rapid determination method of methyl isothiocyanate (MITC) in wine was developed. MITC in wine was extracted with ethyl acetate and the extract was subjected to NPD-GC and GC/MS. The determination limits were $0.02 \mathrm{ppm}$ with NPD-GC, $0.22 \mathrm{ppm}$ with FPD-GC (S-mode) and $0.05 \mathrm{ppm}$ with GC/MS. Recoveries from wine spiked with 0.044 and $0.088 \mathrm{ppm}$ of MITC were $89.4 \%$ and $83.5 \%$, respectively, from white wine and $81.6 \%$ and $75.1 \%$, respectively, from red wine.

MITC in wine imported from Italy was detected in the range of 0.087 to $0.349 \mathrm{ppm}$ in three brands out of 30 examined.

(Received July 16, 1992)

Key words: メチルイソチオシアネート methyl isothiocyanate； ワイン wine；ガスクロマトグ ラフィー gas chromatography

緒訔

イタリアから輸出されたワインの一部にメチルイソチ オシアネート (Methyl isothiocyanate: MITC) の含まれ ていることが米国食品医薬品局 (FDA) の調査で判明し,

*1 国立衛生試験所： T158 東京都世田谷区上用賀 1-18-1

*2 横浜検疫所翰入食品・検疫検查センター： T236 神奈川県 横浜市金沢区長浜 107-8

*3 日本食品分析センター：干206 東京都多摩市永山 6-11-10

*4 日本缶詰検查協会: $\mathbf{T} 231$ 神奈川県横浜市中区北仲道 2-15
厚生省は平成 4 年 4 月 16 日（1992 年），都道府県に対 しこの MITC が混入している疑いがあるワインの販売 を当面中止し，検查を実施するよう通知するとともに， 検疫所に対し輸入時の検查強化を指示した ${ }^{11}$.

MITC は一般に殺虫・殺菌を目的とした土壤くん蒸剤 として使用される農薬であり, 我が国の農薬登録保留基

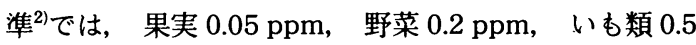
$\mathrm{ppm}$, 茶 $0.1 \mathrm{ppm}$ と規定された農薬である. その毒性は 雄ラットへの経口投与で $\mathrm{LD}_{50} 175 \mathrm{mg} / \mathrm{kg}$ であり ${ }^{3)}$, 皮 
虞, 粘液質膜の侵食及び炎症などがあるといわれてい る.イタリア国内では 1963 年に使用が禁止されるまで 発酵を調節するための添加物として, 主として安価なワ インに使用されることも珍しくなかったという.

MITCの分析法は，ディーンスターク型蒸留装置を用 いる我が国の農薬登録保留基準の方法2)や，有機溶媒で 抽出する方法 ${ }^{4)}{ }^{5)}$ が報告されている. 本法ではそれらを 比較検討した結果として, 酢酸エチルで直接抽出し, こ の抽出液を高周波加熱型フレームサーミオニック検出器 付ガスクロマトグラフ (NPD-GC) で主に定量し, 蛍光光 度検出器付ガスクロマトグラフ (FPD-GC) 及びガスクロ マトグラフーマススペクトロメーター (GC/MS) で確認 する方法を報告する*5).

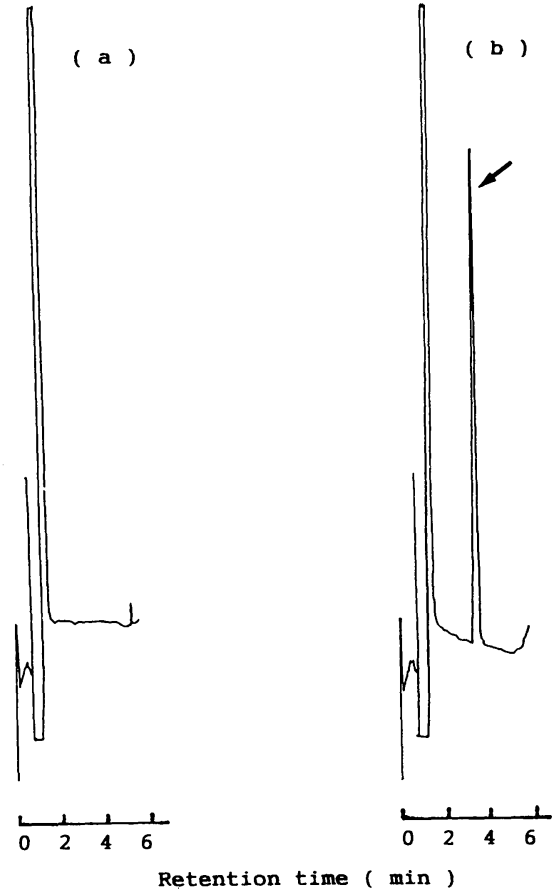

Fig. 1. NPD-Gas chromatogram of MITC in wine extract using a packed columm

(a): wine extract (not spiked)

(b): wine extract (spiked with $2.2 \mu \mathrm{g} / 50 \mathrm{~g}$ of MITC)

Arrow shows MITC peak.

NPD-Gas chromatographic condition -1 : column; $2 \mathrm{~mm}$ i.d. $\times 2 \mathrm{~m}$ (glass), column packing; 25\% PEG 6000, column temp.; $140^{\circ} \mathrm{C}$, injection temp.; $250^{\circ} \mathrm{C}$, detector temp.; $250^{\circ} \mathrm{C}$, carrier gas; $\mathrm{He}(30 \mathrm{ml} / \mathrm{min})$

*5) “ワイン中のメチルイソチオシアネート(MITC) の分析法に ついで平成 4 年 4 月 17 日, 事務連絡 (1992).

\section{実験方法}

\section{1. 実験試料}

平成 4 年 1〜6月に東京港及び横浜港にて輸入された イタリア産ワインを用いた。

2. 試薬, 試夜, 器具

MITC：東京化成工業(株)一級品

酢酸エチル：和光純薬工業(株)残留農薬分析用

\section{3. 装置}

NPD, FPD-GC：(株)横河電機製 HP 5890 シリーズ II；GC/MS：（株）島津製作所製 QP-2000 型

\section{4. 分析操作法}

\section{1 試験溶液の調製法}

試料（ワイン） $50 \mathrm{~g}$ に, 水 $50 \mathrm{ml}$, 塩化ナトリウム 30 $\mathrm{g}$ を加えた後, 酢酸エチル $40 \mathrm{ml}$ で 3 分間振とう抽出し た。

放置し分液後, 上層（酢酸エチル層）を液相分離ろ紙 (Whatman IPS) でろ過し, 少量の酢酸エチルで洗い込 み $50 \mathrm{ml}$ に定容し, 試験溶液とした。

4.2 NPD-GC 測定条件

(1) カラム：25\% PEG 6000/セライト 545 (AW) 80

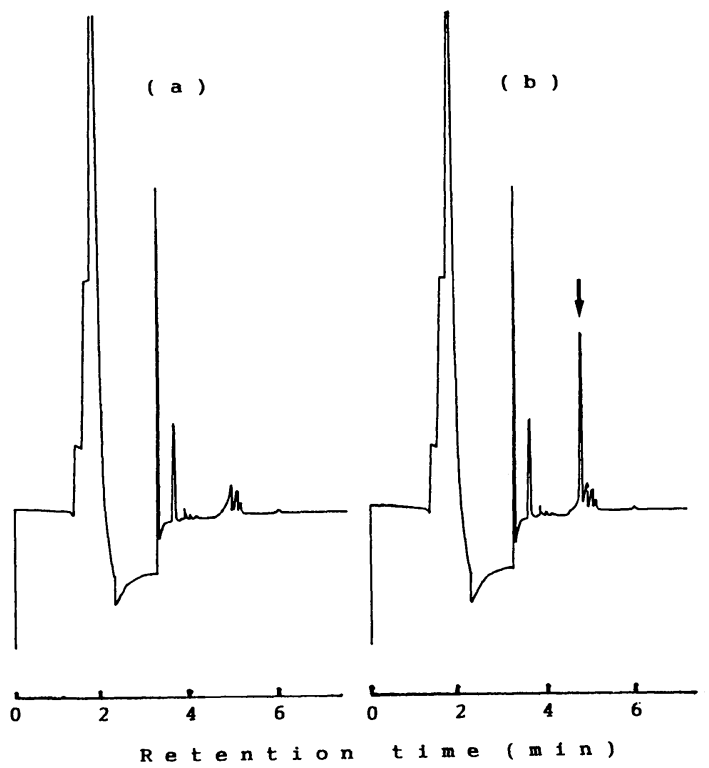

Fig. 2. NPD-Gas chromatogram of MITC in wine extract using a capillary column

(a): wine extract (not spiked)

(b): wine extract (spiked with $2.2 \mu \mathrm{g} / 50 \mathrm{~g}$ of MITC)

Arrow shows MITC peak.

NPD-Gas chromatographic condition -2 : column; DB-17 (J \& W) $0.25 \mathrm{~mm}$ i.d. $\times 30 \mathrm{~m}$, $\mathrm{df}=0.25 \mu \mathrm{m}$, column temp.; $50 \sim 130^{\circ} \mathrm{C}$ (rate $5^{\circ} \mathrm{C} / \mathrm{min}$ ), injection temp.; $250^{\circ} \mathrm{C}$, detector temp.; $150^{\circ} \mathrm{C}$, carrier gas; $\mathrm{He}(60 \mathrm{ml} / \mathrm{min})$ 

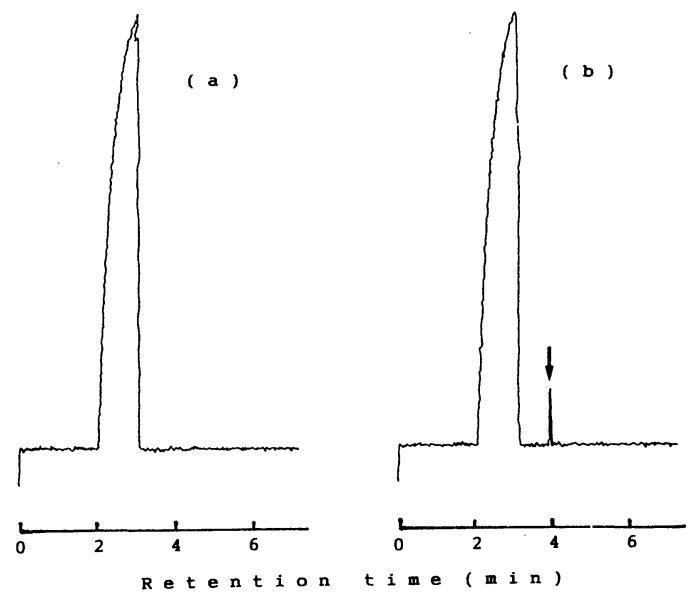

Fig. 3. FPD-(S-mode) gas chromatogram of MITC in wine extract

(a): wine extract (not spiked)

(b): wine extract (spiked with $2.2 \mu \mathrm{g} / 50 \mathrm{~g}$ of MITC)

Arrow shows MITC peak.

Gas chromatographic condition: column; DB-210 (J \& W) $0.25 \mathrm{~mm}$ i.d. $\times 30 \mathrm{~m}, \mathrm{df}=$ $0.25 \mu \mathrm{m}$, column temp.; $50 \sim 130^{\circ} \mathrm{C}$ (rate $5^{\circ} \mathrm{C} / \mathrm{min}$ ), injection temp.; $235^{\circ} \mathrm{C}$, detector temp.; $235^{\circ} \mathrm{C}$, carrier gas; $\mathrm{He}(60 \mathrm{ml} / \mathrm{min})$

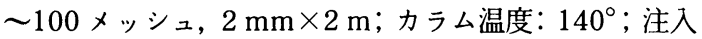
口温度: $250^{\circ}$; 検出器温度: $250^{\circ}$; キャリヤーガス：へ リウム $30 \mathrm{ml} / \mathrm{min}$

(2) カラム: DB-17 ( $\mathrm{J} \& \mathrm{~W}$ 社製) $0.25 \mathrm{~mm} \times 30 \mathrm{~m}$, 膜厚 $0.25 \mu \mathrm{m}$; カラム温度: $50 \sim 130^{\circ}\left(5^{\circ} / \mathrm{min}\right)$; 注入口 温度: $250^{\circ}$; 検出器温度: $150^{\circ} ;$ キャリヤーガス:ヘリ ウム $60 \mathrm{ml} / \mathrm{min}$

4.3 FPD-GC 测定条件 (S モード)

カラム： DB-210 ( $\&$ \& W 社製) $0.25 \mathrm{~mm} \times 30 \mathrm{~m}$, 膜 厚 $0.25 \mu \mathrm{m}$; カラム温度: $50 \sim 130^{\circ}\left(5^{\circ} / \mathrm{min}\right)$; 注入口温 度: $235^{\circ}$; 検出器温度: $235^{\circ} ;$ キャリヤーガス: ヘリウ $\triangle 60 \mathrm{ml} / \mathrm{min}$

\section{$4.4 \mathrm{GC} / \mathrm{MS}$ 測定条件}

カラム：NPD-GC (2) と同じ; カラム温度：50 130 $\left(5^{\circ} / \mathrm{min}\right)$; 注入口温度: $200^{\circ}$; イオン源温度: $250^{\circ}$; セ パレーター温度： $250^{\circ}$; キャリヤーガス：高純度へリウ $ム 1 \mathrm{~kg} / \mathrm{cm}^{2} ;$ 注入法：スプリットレス

\section{実験結果}

\section{MITC の GC 及び GC/MS 測定条件}

NPD-GC, FPD-GC（S モード）及び GC/MS の各 GC 測定条件での MITC のクロマトグラムは Fig. 1, Fig. 2, Fig. 3, 及び Fig. 4 に示したとおり, すべてピーク形状 の良好なクロマトグラムとして測定できた。

NPD-GC 測定条件 (2) では， ワイン由来の小さな三つ

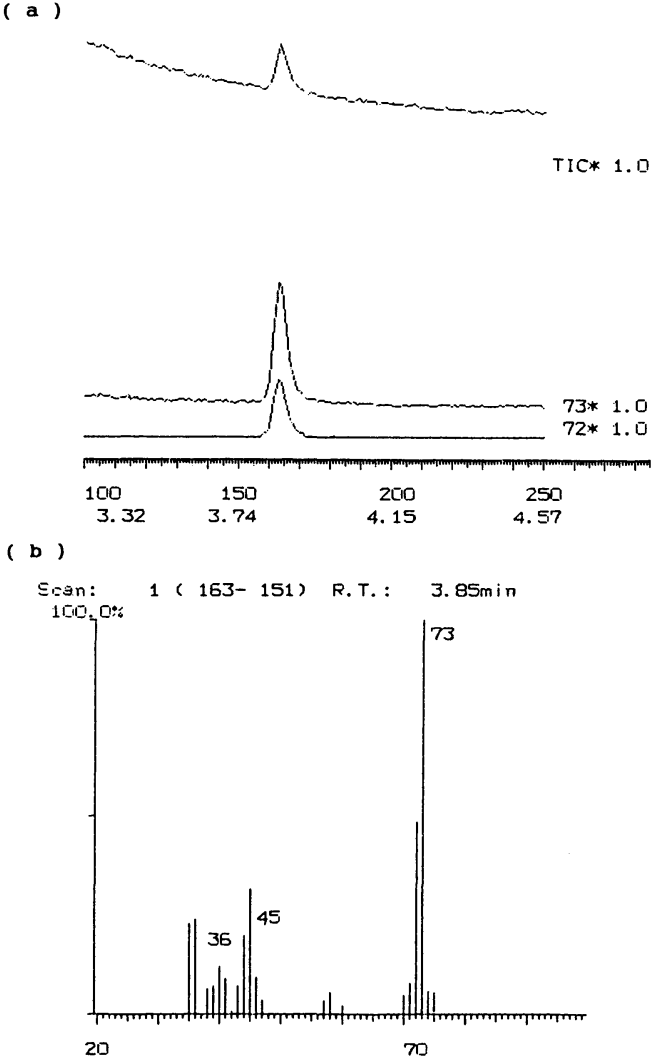

Fig. 4. GC/MS (SIM) Chromatogram of MITC detected in wine extract

(a): mass chromatogram

(b): mass spectram

Gas chromatographic condition: column; DB-17 (J \& W) $0.25 \mathrm{~mm}$ i.d. $\times 30 \mathrm{~m}, \mathrm{df}=0.25$ $\mu \mathrm{m}$, column temp.; $50 \sim 130^{\circ} \mathrm{C}$ (rate $5^{\circ} \mathrm{C} /$ min), injection temp.; $200^{\circ} \mathrm{C}$, detector temp.; $250^{\circ} \mathrm{C}$, ion source temp.; $250^{\circ} \mathrm{C}$, separator, carrier gas; $\mathrm{He}(60 \mathrm{ml} / \mathrm{min})$

のピークが MITC のピークのすぐ後にみられるが，カラ 么の初期温度 $50^{\circ}$ から毎分 $5^{\circ}$ ずつ昇温する条件で十分 な分離が得られた。 その他の条件では特に妨害となるピ 一クは見られなかった. MITCを検出した実際のワイン のクロマトグラムを Fig. 5 に示した.

\section{MITC の検量線}

検量線は NPD-GC 測定条件ではいずれも $0.02 〜 2.2$ ppm の範囲で良好な直線性が得られた。 又 FPD-GC 測 定条件（S モード）では 0.22 2.2 ppm の範囲で良好な 直線性が得られた。

更に GC/MS 測定条件 (Selected ion monitoring: SIM) では $m / z=73$ で測定した時, $0.05 \sim 2.2 \mathrm{ppm}$ の範 囲で良好な直線性が得られた。 


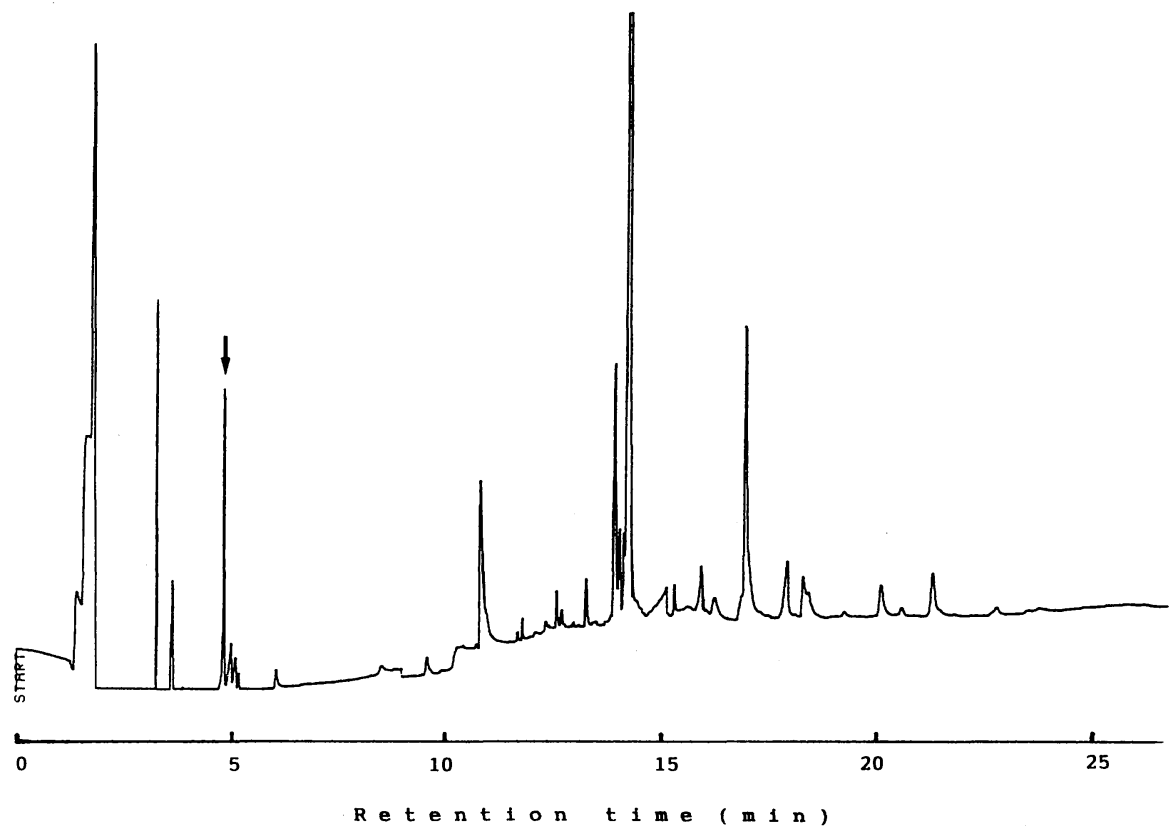

Fig. 5. NPD-Gas chromatogram of MITC detected in wine extract using a capillary column Arrow shows MITC peak.

Gas chromatographic condition: column; DB-17 (J \& W) $0.25 \mathrm{~mm}$ i.d. $\times 30 \mathrm{~m}, \mathrm{df}=0.25$ $\mu \mathrm{m}$, column temp.; $50 \sim 130^{\circ} \mathrm{C}$ (rate $5^{\circ} \mathrm{C} / \mathrm{min}$ ), injection temp.; $250^{\circ} \mathrm{C}$, detector temp.; $150^{\circ} \mathrm{C}$, carrier gas; $\mathrm{He}(60 \mathrm{ml} / \mathrm{min})$

Table 1. Recovery of MITC from Wine of Italy

\begin{tabular}{ccccc}
\hline \hline Kind & $\begin{array}{c}\text { Added } \\
(\mathrm{ppm})\end{array}$ & $\begin{array}{c}\text { Recovery } \\
(\%)\end{array}$ & $\begin{array}{c}\text { Mean } \pm \text { S.D. } \\
(\%)\end{array}$ & $\begin{array}{c}\text { C. V. } \\
(\%)\end{array}$ \\
\hline White & 0.044 & 91.7 & & \\
& & 94.0 & & \\
& & 82.6 & $89.4 \pm 6.0$ & 6.7 \\
& 0.088 & 84.5 & & \\
& & 81.5 & & \\
& & 84.5 & $83.5 \pm 1.7$ & 2.0 \\
Red & 0.044 & 78.7 & & \\
& & 82.2 & & \\
& & 84.0 & $81.6 \pm 2.7$ & 3.3 \\
& 0.088 & 75.3 & & \\
& & 69.8 & & \\
& & 80.3 & $75.1 \pm 5.3$ & 7.1 \\
\hline
\end{tabular}

\section{3. 添加回収実験}

ワインに MITC を $0.044 \mathrm{ppm}, 0.088 \mathrm{ppm}$ 添加した時 の本法で測定した回収率を Table 1 に示した（NPD-GC 測定条件 (2) で測定). 低濃度における添加回収実験でも 89.4\%, 81.6\% と良好な結果を示した。 また，白ワイン， 赤ワインの間に明確な回収率の差はなかった。 ワイン中 の定量下限は NPD-GC ではいずれも $0.02 \mathrm{ppm}$, FPD-GC (S モード) では $0.22 \mathrm{ppm}, \mathrm{GC} / \mathrm{MS}$ (SIM, m) $z=73$ で測定）では $0.05 \mathrm{ppm}$ であり，明確に分離定量 することができた。

\section{4. 輸入イタリア産ワインの分析結果}

平成 4 年 1〜6 月に東京港及び横浜港にて輸入された イタリア産ワイン 30 種について，本法により分析を行 った. Table 2 に結果を示したように 3 銘柄のワインか ら MITC を $0.087 〜 0.349 \mathrm{ppm}$ 検出した.

検出した MITC はすべて GC/MS で確認した。

\section{考察}

実際のワインでは, NPD-ガスクロマトグラフィー (Fig. 5) に見られるようにワイン由来の小さな三つのピ 一クが MITC のピークのすぐ後にみられた.これらのピ ークはカラムの昇温時間が早いと MITC のピークと重 なるが, 本法の条件で十分な分離が得られた。 カラムの 昇温温度を $1 \sim 4^{\circ}$ と小さくしても分離度は変わらなかっ た.

検量線は NPD-GC 測定条件では $0.02 〜 2.2 \mathrm{ppm}$ と MITC の実用分析として十分な幅を示した。

また FPD-GC（S モード）に比べて感度は 10 倍ほど 良く，実際の分析は NPD-ガスクロマトグラフィーでピ 一クが見られた場合, 確認法として濃縮して FPDーガ スクロマトグラフィー（Sモード）及びガスクロマトグ ラフィー/質量分析法の方法を用いて確認を行うことが 望まれた。 
Table 2. Contents of MITC in Wine of Italy

\begin{tabular}{|c|c|c|}
\hline $\begin{array}{l}\text { Sample } \\
\text { number }\end{array}$ & Kind & $\begin{array}{l}\text { Result } \\
\text { (ppm) }\end{array}$ \\
\hline 1 & White & N.D* \\
\hline 2 & " & N.D \\
\hline 3 & " & N.D \\
\hline 4 & " & N.D \\
\hline 5 & " & N.D \\
\hline 6 & " & N.D \\
\hline 7 & "' & N.D \\
\hline 8 & "I & N.D \\
\hline 9 & " & N.D \\
\hline 10 & " & N.D \\
\hline 11 & Red & 0.087 \\
\hline 12 & White & 0.206 \\
\hline 13 & Rose & 0.349 \\
\hline 14 & Red & N.D \\
\hline 15 & White & N.D \\
\hline 16 & " & N.D \\
\hline 17 & $"$ & N.D \\
\hline 18 & " & N.D \\
\hline 19 & $" \prime$ & N.D \\
\hline 20 & " & N.D \\
\hline 21 & Rose & N.D \\
\hline 22 & White & N.D \\
\hline 23 & Red & N.D \\
\hline 24 & " & N.D \\
\hline 25 & White & N.D \\
\hline 26 & " & N.D \\
\hline 27 & "I & N.D \\
\hline 28 & Red & N.D \\
\hline 29 & Rose & N.D \\
\hline 30 & White & N.D \\
\hline
\end{tabular}

* N.D: not detected

Determination limit of MITC was $0.02 \mathrm{ppm}$.

ワイン中の MITC の抽出法について, 農薬登録保留基 準 ${ }^{2)}$ では, ディーンスターク型蒸留装置を用い果実, 野 菜, いも類, 抹茶の場合へキサンで, 茶 (抹茶を除く)の 場合, 酢酸エチルで抽出した後, 塩化ナトリウムを加え 振とうし, 放置し上層を分液後, 液相分離乃紙でろ過し GC で測定している．著者らはディーンスターク型蒸留 装置を用いず, MITC は揮散性が高く濃縮などの操作は 不適当であるので, 直接ワインに酢酸エチル, 水, 塩化 ナトリウムを加え振とうする簡易な試験溶液の調製法を 設定した。このような直接抽出法であワイン中の成分か ら MITC を分離定量できた。酢酸エチル層の分離操作 は, 遠心分離 $(3,000 \mathrm{rpm}, 5$ 分間) であ可能であった。 クロマトグラムを見ても妨害物の影響は見られなかっ た. 分析 1 サイクル約 30 分の繰り返し注入を 100 回以 上行っているが, ベースラインのみだれや異常ピークの 出現は見られなかった。 また, 検量線や MITC のピーク
のリテンションタイムの再現性も保持されている.な お, WHO/FDA ${ }^{4)}$ では試料からの MITC の抽出溶媒と してジクロロメタンを用いているが, 一般に塩素系有機 溶媒の注入は GC の検出器に悪影響を与えると言われて いるので好ましくないと思われる。 また，ジェチルエー テル ${ }^{5)} ゙$ は振とう抽出した際にエマルジョンを生じるの で好ましくなかった。

ワインに MITCを $0.044 \mathrm{ppm}, 0.088 \mathrm{ppm}$ 添加した時 の本法で測定した回収率は, 白ワインで $89.4 \%, 83.5 \%$, 赤ワインで $81.6 \%, 75.1 \%$ であった（NPD-GC 測定条件 (2) で測定). 白ワインの方が赤ワインより回収率が良か ったのは, 赤ワインでは白ワインよりエマルジョンがで きやすく分離が困難になるためと思われる。

NPD がなく FPD (S モード) のみで測定する場合, 試 料を濃縮する必要があるが, 濃縮方法としてエバポレー 夕を用いると，MITC はすべて溶媒とともに揮散してし まい測定できない， $\mathrm{N}_{2}$ 気流下で秪やかに濃縮する方法 で，2〜20 倍に濃縮した場合，揮散による減少はおおよ そ $20 \%$ 程度であった。

検出した MITC のレベルは米国で検出された 0.03〜 $1.35 \mathrm{ppm}^{6)}$ と同じレベルの残留を認めた.

MITC は催奇形性能があり, 米国環境保護局 (EPA) か らのデー夕に基づくと， ワイン $1,000 \mathrm{ml} /$ 日の消費を想 定した場合, 妊婦への許容值は $2 \mathrm{ppm}$, その他の成人へ の許容值は $8 \mathrm{ppm}$ と推断している た量では直ちに人体に影響はないと思われるが，日本で この MITC が検出されたワインは食品衛生法第 6 条違 反（指定外添加物の使用）として措置された.

\section{まと め}

1) ワイン中のメチルイソチオシアネート(MITC) の 簡易かつ迅速な分析法を確立した。

2) MITCは試料から酢酸エチルで抽出, 直接 NPD-GC で定量した。 また, FPD-GC (S モード) 及び GC/MS でも確認した.

3) 試料に $0.044 \mathrm{ppm}, 0.088 \mathrm{ppm}$ 添加した時の回収 率は，白ワインで $89.4 \%, 83.5 \%$, 赤ワインで $81.6 \%$, 75.1\% であった。

4) 本法の定量限界はNPD-ガスクロマトグラフィー では $0.02 \mathrm{ppm}, \mathrm{FPD}$ ガススクロトグラフィー（S モー ド）では $0.22 \mathrm{ppm}$, ガスクロマトグラフィー/質量分析 法では $0.05 \mathrm{ppm}$ であった。

5）イタリア産ワイン 30 銘柄について分析を行っ た.

このうち 3 銘柄から $\mathrm{MITC}$ を $0.087 〜 0.349 \mathrm{ppm}$ 検 出した.

\section{謝辞}

本研究を行うに当たり，MITC に関する情報の提供を いただいた厚生省生活衛生局食品保健課, 高谷幸氏及び 加地祥文氏, 同検疫業務管理室, 中嶋健介氏並びに分析 
法の設定に関するご協力をいただいた東京都立衛生研究 所田村行弘氏, 愛知県衛生研究所早川順子氏はじめ各衛 生研究所の諸先生, 及び MITC の試薬の提供をいただい た国立衛生試験所食品添加物部武田明治氏, 並びに試料 の送付についてご協力いただいた東京検疫所食品監視課 諸氏及び横浜検度所食品監視課諸氏に深謝いたします。

文献

1) 生活衛生局食品保健課検度業務管理室長通知：“イタリア 産ワインの取り扱いについで 平成 4 年 4 月 16 日, 衛検
第 115 号 (1992).

2) 農薬環境保全対策研究会編：“農薬登録保留基準ハンドブ ック” p. 454〜456 (1990), 化学工業日報社.

3) 富沢長次郎, 上路雅子, 腰岡政二編: “最新農薬データブ ック” p. 244〜245 (1989), ソフトサイエンス社.

4) Carbone, D.: Riv. Vitio. Enol., 40(10), 478 485 (1987).

5) Glrenko, D. B., Klisenko, N. A.: Gig. Sanit. (3), 48 49 (1987).

6) Rothsdrild, L.: Food Chemical News, 34, 3 4 (1992). 